\title{
Exchange Rate Risk Exposure of Nigerian Listed Firms:
}

\section{An Empirical Examination}

\author{
ASAOLU Taiwo Olufem \\ Department of Management and Accounting, Faculty of Administration \\ Obafemi Awolowo University, Ile-Ife, Nigeria \\ Tel: 234-803-721-6060 E-mail: tasaolu@oauife.edu.ng or taiwoasaolu@ymail.com
}

Received: May 26, 2010 Accepted: June 12, 2010 doi:10.5539/ibr.v4n2p219

\begin{abstract}
The study investigated foreign exchange rate risk exposure of 117 samples of Nigerian Listed firms for the period 1998 - 2007. The Jorion (1991) approach of measuring economic exposure as a slope coefficient of the regression of stock returns on exchange rates movements was used. The study utilized three alternative currencies exchange rates, viz; the US Dollar, the UK Pounds and the Euro effective real exchange rates. Findings reveal that Nigerian listed firms are generally exposed to adverse exchange rates risks of the three currencies under investigation, with a higher magnitude of exposure to the US dollar. The study further investigated differences in exposure by financial and non-financial sector firms. The results failed to indicate any significant differences in pattern of exposure between the financial and non-financial firms, thus providing no evidence to support the thesis that financial firms possess requisites to hedge exchange rates risks. The study concluded that exchange rates instability is significant hindrance to corporate performance in Nigerian listed firms.
\end{abstract}

Keywords: Exchange Rates, Risk Exposure, Nigerian Firms

\section{Introduction}

In Nigeria, foreign exchange management policies have traversed the extremes of fixed and flexible regimes with a view to preserve the value of the domestic currency, the naira; maintain a favorable external reserves position, and ensure price stability. It shifted from a fixed regime in the 1960s to a pegged arrangement between the 1970s and the mid-1980s. The fixed exchange rate regime induced an overvaluation of the naira, necessitating it's been supported by exchange control regulations that engendered significant distortions in the economy that gave vent to massive importation of finished goods with the adverse consequences for domestic production, balance of payments position and the nation's external reserves level. Moreover, the period was bedeviled by sharp practices perpetrated by dealers and end-users of foreign exchange. These and many other structural problems in the Nigerian economy necessitated the adoption of the Structural Adjustment Programme (SAP) in 1986, aimed at revamping the ailing economy, eliminate the distortions in the economy and to predispose it to sustainable growth. Under the programme, several reforms measures were designed to restructure and diversify the productive base of the economy, achieve fiscal balance and balance of payments viability, intensify the growth potential of the private sector and set the economy on the path of steady and balanced growth.

Consequent upon achieving the foregoing, foreign exchange market reforms constituted one of the main policy thrusts of structural adjustment with the adoption of a more flexible exchange rate regime. Since 1986, exchange rates management has passed through various types of the floating regime with a regime of managed float, without any strong commitment to defending any particular parity, being the predominant characteristic of the floating regime in Nigeria. The resultant effect of the foregoing has been unstable movements in exchange rates occasioned by incessant regime changes over the years. Variability in exchange rate is a major source of macroeconomic uncertainty affecting firms. The implication of considerable exchange rate fluctuations over the last three decades, which is of policy and research relevance in Nigeria, is its risk exposure to domestic agents. More specifically, it is widely believed that changes in exchange rates have important implications for financial decision-making and for the profitability of firms.

Michael Adler and Bernard Dumas (1984) define a firm exposure to exchange rate risks when its share value is influenced by changes in currency values. There are theoretically various channels through which the exchange rate might affect the profitability of a firm. Firms that export to foreign markets may benefit from a depreciation of the local currency if its products become more affordable to foreign consumers. On the other hand, firms that rely on 
imported intermediate products may see their profits shrink as a consequence of increasing costs of production. Even firms that do no international business may be influenced indirectly by foreign competition. Furthermore, firms in the non-traded as well as the traded sectors of the economy compete for factors of production, whose returns may be affected by changes in the exchange rate.

The motivation for the current study is two pronged. First, while large bodies of empirical studies provide evidence for the relationship between foreign exchange rate movements and changes in the value of firms, results from these studies are diverse and inconclusive. While Many studies, have found the exchange rate exposure significant (Allayannis, 1997; Allayannis and Ihrig, 2002; Dominguez and Tesar, 2001; Griffin and Stulz, 2001; Chow, Lee and Solt, 1997), many other studies argue that the value impact of exchange rate is weak (Jorion (1991) Bodnar and Gentry (1993)

Secondly, existing studies have concentrated on large firms operating within well-developed money and capital markets of industrialized economies of US and United Kingdom. Findings from these studies becomes difficult to generalized for relatively small sized firms in Nigeria that operates within a relatively segmented and less efficient markets, especially bearing in mind the argument that in the efficient markets, the exchange rate changes do not matter, as they are absorbed instantly. Specific research studies exclusively on the subject of exchange rate exposure of firms in developing countries, especially in poor Sub Saharan African (SSA) countries remained altogether an ignored area of empirical research. The only study, to our knowledge is Zubeiru, Kofi and Adjasi (2007) for the Ghanian firms. These we argue are serious shortcomings of existing literature, and the current study fills the gap for Nigerian economy and also adds to the limited body of empirical literature on exchange rate exposure of firms in Africa. Results of this study will serve as a useful guide to corporate managers and investors on the degree of foreign exchange exposure and the need to effectively manage firm exposure.

The rest of the study is structured as follows. Section two gives a brief review of exchange rate management in Nigeria; section three reviews the extant literature on foreign exchange exposure. Section four presents the methodology adopted for the study while section five discusses the findings. Conclusions from the study are drawn in section six.

\section{A Brief Review of Exchange Rate Policy in Nigeria}

Following the failure of previous macroeconomic policies to turn round the economy, Nigeria adopted SAP in September, 1986, the major element of which was the pursuant of a realistic exchange rate. With the introduction of SAP, the second-tier Foreign Exchange Market (SFEM) was established. SFEM was expected to produce a market-determined exchange rate that would remove the overvaluation of the naira, which persisted in the pre-SAP era. Since 1986, various exchange rate policies, ranging from dual exchange to unified exchange rate system in 1987 were adopted. In 1994, regulation of the foreign exchange market was re-introduced with rate fixed at N22/US\$1. However, because of inherent abuses and bureaucratic bottlenecks associated with regulation the system was short-lived. In 1995, the Autonomous Forex Market (AFEM) was introduced following the promulgation of Foreign Exchange (Monitoring and Miscellaneous Provisions) Decree 17 of 1995 and the abolition of Exchange Control Act of 1962. Under the AFEM, CBN was to intervene in the market as short notice.

Failure of AFEM led to introduction of Inter-bank Foreign Market (IFEM), a pre-cursor to Dutch Auction System (DAS) in October, 1999. IFEM was aimed at, among others, deepening inter-bank foreign exchange market as well as having a stable naira exchange rate. Developments in IFEM namely, persistent high demand for forex, continued depreciation of the naira with premium between official rate and those in the parallel market widening from N7.0470/\$1 in 1999 to N16.3808/US\$ in 2002, and continued depletion of reserves position led to its abandonment and the re-introduction of DAS in July 2002. Having previously been introduced in 1987 and 1990-91, DAS was re-introduced to address the failures of IFEM. Specifically, it was geared towards achieving the following: determination of exchange rate of naira; conserve external reserve position; reduce the premium between official rate and the parallel market; and ensure stability of the naira exchange rate.Having operated DAS for about three and half years, the CBN in 2005 introduced the Wholesale Dutch Auction System (WDAS) which has since being in operation.

\section{Exchange Rate Exposure: Empirical Review}

Economic theory postulates that under a floating exchange rate regime, changing exchange rates affect the competitiveness of firms, especially those engaged in international trade. Home currency depreciation promotes the competitiveness of firms in home country by allowing them to undercut prices charged for goods manufactured abroad (Luehrman, 1991). On the other hand, exchange rate appreciation reduces the competitiveness of export markets; it has a negative effect on the domestic stock market. Conversely, if the country is import denominated, 
exchange rate appreciation may have positive affect on the stock market by lowering input costs. Thus, an increase in the value of the home country firm in response to a real drops in the value of the home currency.

A considerable number of studies aimed at testing the foregoing postulates have been conducted to determine the exposure of firms to exchange rate movements. Not only that these studies have been inconclusive on the nature of exchange rate exposure, they have been largely conducted on industrialized economies. In what follows, we undertake a review of the extant literature on exchange rate exposure.

Jorion (1991) empirical investigation of the sensitivity of the stock prices of US multinationals to changes in dollar exchange rates is seminal in empirical investigation of exchange rate exposure. His empirical results indicated that the sensitivity of stock prices to changes in exchange rate is not significant at any accepted level of significance.

Luetherman (1991) tested the hypothesis that an exogenous real home currency depreciation enhance the competitiveness of home country manufacturers vis a vis foreign competitor. His finding did not support that hypothesis. Firms did not benefit from a depreciation of the home country. On the contrary a significant decline in their market share of industry was found in a depreciation of the home currency.

Bodnar and Gentry (1993) examined the relationship between exchange rate changes and industry portfolio returns for Canada, Japan and the United States between 1979 and 1988. The study revealed that less than half of the industries display significant exchange rate exposure at the $10 \%$ significant level in these countries.

AlDiab, Zoubi, and Thornton (1994) examine the impact of changes in the dollar exchange rate on daily security returns of US multinational companies. The study made use of an event study methodology for the period 1978 to 1987, and concluded that the stock prices of Multinational Companies are not greatly affected by changes in exchange rates or that the relationship is weak.

Donnelly and Sheehy (1996) examine the relationship between changes in trade-weighted nominal exchange rate and the monthly abnormal returns of portfolio of the UK's 39 largest exporting firms during the period 1978 to 1992. The study finds a contemporaneous negative relationship between the foreign exchange changes and the abnormal returns of UK exporters.

Fang and Loo (1994) investigate the effect of unanticipated changes in the US trade-weighted exchange rate on US industries' common stock returns over the period 1981 to 1990 . The study recorded significant negative betas for the mining, food and beverage, chemical, petroleum and utilities industries, whereas, positive exchange rate risks betas are observed in retail and apparel, machinery, transportation equipment, department stores, and miscellaneous industries.

Glaum, Brunner and Himmet (2000) examined the economic exposure of German corporations to change in DM/US dolar exchange rate. They found that German firms are significantly exposed to changes in DM/US dollar rate.

Krishnamoorthy (2001) examines whether the industrial structure is an important determinant of the exchange rate exposure of US industry portfolio returns over 1995-1997 period. The study indicated that industries that are classified as being globally competitive and those that serve the consumer sector of the economy have significant levels of exposure.

Chang (2002) used the two-factor model of Jorion (1990) to examine industry-level currency risk of Taiwan's stock market around the Asian financial crisis. Conclusions from the study indicated that export-oriented industries are positively affected by the depreciation of the Taiwan dollar against the US Dollar. The results further show that there is a negative relationship between firm size and currency exposure in Taiwan's stock market, thus finds support for the hypothesis that the exchange rate risk is less for larger firms than for smaller firms as documented by studies such as Nance, Smith and Smithson (1993) and Chow, Lee and Solt (1997).

Joseph (2002) examined the impact of foreign exchange rate changes and interest rate changes on UK firms during the period 1988 to 2000 . He considers two different measures of foreign exchange rate impacts, along with a measure of interest rate changes. The findings show that industry returns are more negatively affected by interest rate changes than by foreign exchange rate changes.

The only study, to our knowledge that explains the exchange rate exposure of firms from an African perspective is that of Zubeiru, Kofi and Adjasi (2007) for the Ghanaian firms. The examined the foreign exchange exposure of listed companies on the Ghana Stock Exchange over the period January 1999 to December 2004. The research uses different exchange rate measures namely; the cedi to US dollar, the cedi to UK pound sterling, the cedi to the euro and a trade-weighted exchange rate index to determine the degree of exposure. The Jorion (1990) two-factor model which regresses the return on a firm against changes in the exchange rate and return on the market was used to estimate the exchange rate exposure for the sample of twenty firms used in the study. About 55 per cent of firms in 
the sample have a statistically significant exposure to the US dollar whilst 35 per cent are statistically exposed to the UK pound sterling. Sector specific exposure results show that the manufacturing and retail sectors are significantly exposed to the US dollar exchange rate risk. The financial sector did not show any risk exposure to any of the international currencies. The most dominant source of exchange rate risk exposure is the US dollar. Most firms are also negatively exposed to the cedi to US dollar exchange rate changes, implying that the cedi depreciation vis-a-vis the US dollar adversely affects firm returns.

\section{Model, Data and Estimation Techniques}

Following earlier studies exchange rate exposure is calculated as the sensitivity of firm returns to exchange rate movements. In order to measure Nigerian firms' economic exposure we followed Adler \& Simon (1986) model. We measure economic exposure as the slope coefficient from a regression of stock returns on exchange rates.

$$
\mathrm{R}_{\mathrm{it}}=\alpha_{\mathrm{i}}+\beta_{\mathrm{i}} \mathrm{EX}_{\mathrm{it}}+\mathrm{e}_{\mathrm{it}}
$$

$\alpha_{i}=$ constant term

$\mathrm{R}_{\mathrm{it}=}$ Stock return for firm $\mathrm{i}$.

$\mathrm{EX}_{\mathrm{t}}=$ Percentage change in exchange rate

The coefficient $\beta_{\mathrm{i}}$ represents the sensitivity of a company i's stock returns to exchange rate movements. In the model, EX represents alternative exchange rates movements. The study considered Nigerian firms exposure to the movements in the Naira to the US dollar, the Naira to the UK pound and the Naira to the euro. Positive value of $\beta_{i}$ means that a depreciation of Naira corresponds to an increase in the value of firm, while negative value represents an adverse exposure to exchange rates movements.

Jorion (1991) introduced another macroeconomic variable market return to control for market movements. To control for the 'common macroeconomic' influences on total exposure elasticities; most emprical studies include the return to a market portfolio with the exchange rate variable in their emprical models (Bodnar \& Wong, 2000).

$$
\mathrm{R}_{\text {it }}=\alpha_{\mathrm{i}}+\beta_{1 \mathrm{i}} \mathrm{EX}_{\mathrm{t}}+\beta_{2 \mathrm{i}} \mathrm{R}_{\mathrm{mt}+} \mathrm{e}_{\mathrm{it}}
$$

$\alpha_{i}=$ constant term

$\mathrm{R}_{\mathrm{it}=}$ Stock return for firm $\mathrm{i}$.

$e_{t}=$ Percentage change in exchange rate

$\mathrm{R}_{\mathrm{mt}}=$ Market return

Ordinary least squares regression will used to estimate models. Exchange rate movements can be measured in nominal or real terms. Real movements are defined as nominal movements adjusted for price level changes. Since real and nominal exchange rates are highly correlated both or one of them are used in most existing studies. The exchange rate used in the study is real effective exchange rate. The market index we employ is nominal interest rate, although we note the presence of high inflation in Nigeria economy. Finally, stock returns were proxied by earning per shares reported in the annual financial summaries of sampled firms.

This study employed secondary data sourced from the Annual reports and Accounts of the sampled firms and FACT BOOK, the annual publications of the Nigerian Stock Exchange. Exchange rates series were sourced from Statistical Bulletin of the Central Bank of Nigeria. Only quoted companies were included in the study because financial information of unquoted companies are not readily available. There are 204 quoted companies listed in the 2008 Nigerian Stock Exchange (NSE) Fact Book. The sample were purposively selected to exclude those with missing data and newly quoted companies, the selection criteria yielded a total of 117 firms, made up of 52 firms in the financial and securities sector companies and 65 firms in the Non financial sector. This sectoral segregation enabled an investigation of possible differentials in exposure by financial and non-financial firms; this becomes necessary, as financial firms possess the reputation for effectively hedging exchange rate risks. This research covers a period of 10 years from $1998-2007$. The sample period and sample size selected seem adequate and comprehensive enough for the kind of analysis intended in this study.

\section{Empirical Results}

In what follows, the results of the Nigerian Companies exchange rates sensitivity are reported. The model in equation 2 was estimated by Ordinary least squares regression method. First we regressed real effective exchange rate change of the three foreign currencies respectively on all sample value. Then sample was divided into two groups as financial and non-financial firms and exchange rate sensitivity of each group was examined. Table 1 to Table 3 below respectively presents summary statistics of sampled firms sensitivity to movements of the Nigerian Naira to the US dollar, the Naira to the UK pound and the Naira to the euro. 
Table 1 above presents estimates of exchange rate sensitivity of Nigerian listed firms to movements in Naira/US dollar real effective exchange rates. Column 2 of the table presents results for all sampled firms, while column 3 and 4 respectively indicated results for the sub-sample divisions into financial and non-financial firms. Exchange rate exposure coefficient for all firms range between -0.012 and 0.644 with mean value of 0.222 . As indicated in the table a total of 103 of total 117 sampled firms indicated a statistically significant dollar exchange rate exposure, representing $88 \%$ of total sampled firms. Further, $23(22.3 \%)$ were positively exposed while $80(77.7 \%)$ were adversely exposed to the dollar.

For the financial sector firms, exposure coefficient ranged between -0.316 and 0.827 with mean value 0.221 .41 $(78.8 \%)$ of 52 financial firms were statistically sensitive to dollar exchange rates movements. 19 firms were positively exposed while the remaining 22 were adversely exposed. The non-financial firms indicated a mean exchange rate exposure coefficient of 0.332. $62(95.3 \%)$ of the 65 sampled non-financial firms were significantly exposed to US dollar exchange rates. Out of these 24 (38.7\%) were favorably exposed while $38(61.3 \%)$ were adversely exposed to the dollar exchange rates.

The summary of results presented above indicated that majority of Nigerian listed firms' returns are sensitive to dollar exchange rates with the largest proportion being adversely exposed. The results failed to indicate any significant differences in pattern of exposure between the financial and non-financial firms, thus providing no evidence to support the thesis that financial firms possess requisites to hedge exchange rates risks. However, non-financial firms has a higher value of mean exposure coefficient compared to financial sector firms.

Table 2 and Table 3 respectively present results of Nigerian firms sensitivity to changes in UK pounds and the Euro real effective exchange rates. Similar to the results presented above, Nigerian listed firms are generally exposed to risks of exchange rates movements. $88(75.2 \%)$ of total sampled firms were significantly exposed to risks of UK pounds exchange rates movements, while $63(53.8 \%)$ were significantly exposed to the Euro. In general terms, larger proportion of exposure incidence were adverse exposure, indicating that exchange rates instability are significant hindrance to corporate performance in Nigerian listed firms.

Overall the regression equations have good statistical fit with the $t$ values significant for most variables. The adjusted $R^{2}$ and $R$ were sufficiently high indicating that the independent variables explained sufficient quantity of the variations in the dependent variables. Durbin Watson Statistic (DW) also reveals the absence of serious auto correlation for all the equations. These test results shows the reliability of our estimated equations in modeling the problem under investigation.

\section{Summaries and Conclusion}

The study investigated foreign exchange rate risk exposure of 117 samples of Nigerian Listed firms for the period 1996 - 2005. The Jorian (1991) approach of measuring economic exposure as a slope coefficient of the regression of stock returns on exchange rates movements was used.

The study utilized three alternative currencies exchange rates, viz; the US Dollar, the UK Pounds and the Euro effective real exchange rates. Findings reveal that Nigerian listed firms are generally exposed to adverse exchange rates risks of the three currencies under investigation, with a higher magnitude of exposure to the US dollar.

The study further investigated differences in exposure by financial and non-financial sector firms. The results failed to indicate any significant differences in pattern of exposure between the financial and non-financial firms, thus providing no evidence to support the thesis that financial firms possess requisites to hedge exchange rates risks.

The study concluded that exchange rates instability are significant hindrance to corporate performance in Nigerian listed firms. For policy, monetary and exchange rates management should emphasize achieving sustainable stability in exchange rates movements.

\section{References}

Adler, M. and B. Dumas. (1984). Exposure to Currency Risk: Definition and Measurement, Financial Management, $41-50$.

Adler, M. and Simon, D. (1986). Exchange risk surprises in international portfolios. Journal of Portfolio Management, Vol 12 No 2, pp. 44-53.

AlDiab, T.F., M.M, Zoubi, and P.W. Thornton. (1994). The effect of changes in the dollar foreign exchange rate on stock returns of multinational corporations. Journal of Applied Business Research, Vol.10.

Allayannis, G. (1997). The Time-Variation of the Exchange-Rate Exposure: An Industry Analysis, University of Virginia working paper. 
Allayannis, George and Jane Ihrig. (2002). Markups and Exposure. Review of Financial Studies, 14, no3, p805-835.

Bodnar, Gordon and Gentry, William. (1993). Exchange-rate exposure and industry characteristics: evidence from Canada, Japan and U.S. Journal of International Money and Finance, 1993,12(1), pp. 29-45.

Chang, Y. (2002). The Pricing of foreign exchange risk around the Asian Financial crisis: Evidence from Taiwan's stock market, Journal of Multinational Financial Management. Vol.12.

Chow, E. H., Lee, W. Y. and Solt, M. E. (1997). The exchange-rate risk exposure of asset Returns. Journal of Business 70, 105-123.

Dominguez, Kathryn and Tesar, Linda. (2000).Exchange Rate Exposure. Mimeo, University of Michigan.

Donnelly, R., and E. Sheehy. (1996). The share price reaction of U.K exporters to exchange rates movements: An Empirical study. The Journal of International Business Studies, Vol.27.

Fang, H and J.C. Loo. (1994). Dollar value and stock returns. International Review of Economics and Finance, Vol.3.

Brunner, M., Glaum, M. and Himmel, H. (2000). The DAX and the Dollar: the economic exchange rate exposure of German corporations. Journal of International Business Studies, Vol 31, No 4, pp. 715-724.

Griffin, J.J and R. Stulz. (2001). International competition and exchange rate shocks: A cross-country industry analysis of stock returns, Review of Financial Studies, vol 14.

Jorion, P. (1990). The Exchange rate exposure of U.S. multinational. Journal of Business, Vol. 63 No: 3,_331-345.

Jorion, P. (1991). The Pricing of Exchange Rate Risk in Stock Market, Journal of Financial and Quantitative Analysis, September, 363-376.

Joseph, N.L. (2002). Modelling the impacts of interest rate and exchange rate changes on UK stock returns. Derivatives Use, Trading and Regulation, Vol. 7.

Krishnamoorthy, A. (2001). "The impact of industrial structure and the exchange rate exposure of industry portfolio returns" Global Finance Journal, Vol.12.

Luehrman, T. A. (1991). Exchange Rate Changes and the Distribution of Industry Value. Journal of International Business Studies, 22, 619-649.

Nance, D., C. Smith \& C. Smithson. (1993). On the determinants of corporate hedging. Journal of Finance, Vol.48.

Zubeiru, Kofi \& Adjasi. (2007). Foreign exchange risk exposure of listed companies in Ghana. The Journal of Risk Finance Incorporating Balance Sheet, Volume 8, Number 4.

Table 1. Foreign Exchange Rate Exposure of Nigerian Firms to the US Dollar

\begin{tabular}{|c|c|c|c|}
\hline & All Firms & Financial Firms & Non-Financial Firms \\
\hline Sample Size & 117 & 52 & 65 \\
\hline Exposure Coefficient $\left(\beta_{i}\right)$ : Mean & 0.222 & 0.221 & 0.332 \\
\hline Minimum & -0.012 & -0.316 & -0.233 \\
\hline Maximum & 0.644 & 0.827 & 0.772 \\
\hline \multicolumn{4}{|l|}{ Significant Exposure: } \\
\hline \multirow{2}{*}{$\begin{array}{c}\text { Number of Firms } \\
\text { Percentage of Total }\end{array}$} & 103 & 41 & 62 \\
\hline & $88 \%$ & $78.8 \%$ & $95.3 \%$ \\
\hline \multicolumn{4}{|l|}{ Sign of Exposure Coefficient $\left(\beta_{i}\right)$ : } \\
\hline \multirow{2}{*}{$\begin{array}{l}\text { Positive } \\
\text { Negative }\end{array}$} & $23(22.3 \%)$ & $19(46.3 \%)$ & $24(38.7 \%)$ \\
\hline & $80 \quad(77.7 \%)$ & $22(53.7 \%)$ & $38(61.3 \%)$ \\
\hline
\end{tabular}

Source: Author's computations from OLS regression analyses. 
Table 2. Foreign Exchange Rate Exposure of Nigerian Firms to the UK Pound

\begin{tabular}{|c|c|c|c|}
\hline & All Firms & Financial Firms & Non-Financial Firms \\
\hline Sample Size & 117 & 52 & 65 \\
\hline \multirow[t]{3}{*}{ Exposure Coefficient $\left(\beta_{\mathrm{i}}\right)$ : Mean } & 0.321 & 0.432 & 0.115 \\
\hline & -0.188 & -0.211 & -0.413 \\
\hline & 0.812 & 0.734 & 0.791 \\
\hline \multirow{3}{*}{$\begin{array}{l}\text { Number of Firms } \\
\text { Percentage of Total }\end{array}$} & & & \\
\hline & 88 & 32 & 56 \\
\hline & $75.2 \%$ & $61.5 \%$ & $86.1 \%$ \\
\hline \multirow[t]{3}{*}{ Sign of Exposure Coefficient $\left(\beta_{\mathrm{i}}\right)$ : } & & & \\
\hline & $23(26.1 \%)$ & $19(59.4 \%)$ & $24(42.8 \%)$ \\
\hline & $65(73.9 \%)$ & $13(40.6 \%)$ & $32(57.2 \%)$ \\
\hline
\end{tabular}

Source: Author's computations from OLS regression analyses.

Table 3. Foreign Exchange Rate Exposure of Nigerian Firms to the Euro

\begin{tabular}{|c|c|c|c|}
\hline & All Firms & Financial Firms & Non-Financial Firms \\
\hline Sample Size & 117 & 52 & 65 \\
\hline \multirow[t]{3}{*}{ Exposure Coefficient $\left(\beta_{\mathrm{i}}\right)$ : Mean } & 0.255 & 0.127 & 0.221 \\
\hline & -0.321 & -0.251 & -0.254 \\
\hline & 0.822 & 0.776 & 0.654 \\
\hline \multirow{3}{*}{$\begin{array}{l}\text { Number of Firms } \\
\text { Percentage of Total }\end{array}$} & & & \\
\hline & 63 & 29 & 34 \\
\hline & $53.8 \%$ & $55.7 \%$ & $52.3 \%$ \\
\hline \multirow{3}{*}{ Sign of Exposure Coefficient $\left(\beta_{\mathrm{i}}\right)$ : } & & & \\
\hline & $23(36.5 \%)$ & $19(65.5 \%)$ & $14(41.2 \%)$ \\
\hline & $40 \quad(63.5 \%)$ & $10(34.5 \%)$ & $20(58.8 \%)$ \\
\hline
\end{tabular}

Source: Author's computations from OLS regression analyses. 